Lisbon - Malacca Port Cities Twin Conferences 2019 / 2020

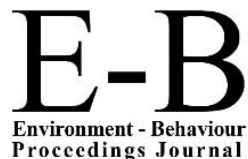

AicQoL2020Malacca

ASLI (Annual Serial Landmark International) Conferences on QoL2020

https://www.amerabra.org; https://fspu.uitm.edu.my/cebs; https://www.emasemasresources.com/

8th AMER International Conference on Quality of Life

Mahkota Hotel Melaka, Malacca, Malaysia, 18-19 Mar 2020

(Due to the Covid-19 lockdown, paper virtually presented on 25 Mar 2020)

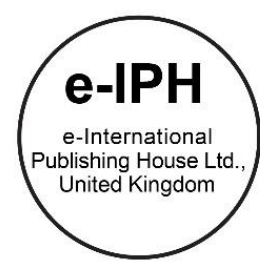

\title{
Pathway to Financial Well-being: A review on the role of psychological factors
}

\author{
Mohd Samsuri Ghazali, Sharifah Faigah Syed Alwi, \\ Nurul Nadia Abd Aziz, Siti Fahazarina Hazudin
}

Faculty of Business and Management,

Universiti Teknologi MARA (UiTM). 40450. Shah Alam. Selangor. MALAYSIA

mohdsamsuri@uitm.edu.my; shfaigah@uitm.edu.my; nurul_nadia@uitm.edu.my; fahazarina@uitm.edu.my Tel: $0126841260 \mathrm{~T}$

\begin{abstract}
This paper aimed to complete a rigorous, systematic exploration of the literature investigating the effects of psychological factors on the financial wellbeing in Malaysia context. We identified 13 papers that report empirical evidence on the effect of psychological factors on the financial well-being in Malaysia context. The findings conclude that the studies in financial well-being are focusing on four groups of respondents namely college student young employees, singles mothers and Muslim individual and the eleven types of psychological variables are identified. This assemblage of reviewed research papers will be useful for the academia and government to cultivate understanding on the psychological rumblings of an individual and leading to greater financial well-being, hence uplifting the quality of life of affected parties.
\end{abstract}

Keywords: Financial well-being; Financial behaviour; Psychological Factors;

eISSN: 2398-4287 @ 2020. The Authors. Published for AMER ABRA cE-Bs by e-International Publishing House, Ltd., UK. This is an open access article under the CC BYNC-ND license (http://creativecommons.org/licenses/by-nc-nd/4.0/). Peer-review under responsibility of AMER (Association of Malaysian Environment-Behaviour Researchers), ABRA (Association of Behavioural Researchers on Asians) and cE-Bs (Centre for Environment-Behaviour Studies), Faculty of Architecture, Planning \& Surveying, Universiti Teknologi MARA, Malaysia. DOI: https://doi.org/10.21834/e-bpj.v5i13.2063

\subsection{Introduction}

In 2015, the United Nations (UN) introduced the Sustainable Development Goals (SDGs), which describe an agenda to transform our world by 2030 by providing a holistic and multidimensional view of development to ensure well-being, economic prosperity, and environmental protection (Pradhan, Costa, Rybski, Lucht, \& Kropp, 2017). These goals are a wakeup call to all UN members to show their commitment and effort in achieving the goals. Among the 17 goals, the top three focus on poverty elimination (SDG 1), zero hunger (SDG 2), and good health and well-being (SDG3) (United Nations, 2015) which is related to the financial well-being of the public. To achieve the goals, financial well-being is becoming the main agenda of each country's policies and development. Financial well-being is also increasingly a topic of interest for scholars of various disciplines, especially economics, psychology, and sociology (Brüggen, Hogreve, Holmlund, Kabadayi, \& Löfgren, 2017; Sorgente \& Lanz, 2017). In Malaysia, the launch of the Malaysian National Strategy for Financial Literacy in 2019 is parallel with the world objective of improving the public financial well-being (Financial Education Network, 2019) which its shows Malaysian commitment and support for achieving the goals for a better world, hence uplifting the quality of life of affected parties.

\subsection{Issues, research problem and research questions}

According to (O'Neill., Sorhaindo., Xiao., \& Garman., 2005; Prawitz et al., 2006), financial well-being is the primary factor that affects personal well-being. The individual that can handle their finances well will maintain positive well-being, however, disturbance in

eISSN: 2398-4287 @ 2020. The Authors. Published for AMER ABRA cE-Bs by e-International Publishing House, Ltd., UK. This is an open access article under the CC BYNC-ND license (http://creativecommons.org/licenses/by-nc-nd/4.0/). Peer-review under responsibility of AMER (Association of Malaysian Environment-Behaviour Researchers), ABRA (Association of Behavioural Researchers on Asians) and cE-Bs (Centre for Environment-Behaviour Studies), Faculty of Architecture, Planning \& Surveying, Universiti Teknologi MARA, Malaysia.

DOI: https://doi.org/10.21834/e-bpj.v5i13.2063 
individuals' financial well-being will cause long-term ramifications on their psychological, emotional, and relational well-being (So-hyun Joo \& John E. Grable, 2004). There are three leading indicators in evaluating financial well-being which include the amount of future savings (Andrea Finney, 2016) level of debt (Andrea Finney, 2016; Gutter \& Copur, 2011)and bankruptcy rate(Xiao, 2013).

The situation in Malaysia indicates the alarmingly low level of financial well-being in the country. Murugiah (2016)claimed that Malaysia household debt is at a red flag level despite dropping to 84.6 per cent in 2017, from 88.4 per cent in 2016 (Bank Negara Malaysia, 2017). Besides, Malaysian saving is considered low due to weaker growth compared to the previous year. The amount of deposit grew at $6.74 \%$ between 2014 and 2015 compared to 3.98\% between 2016 and 2017. Furthermore, the Malaysia Insolvency Department (2017) declared bankruptcy on 294,000 individuals in Malaysia due to their failure to settle numerous financial commitments such as hire-purchases, credit cards, personal and housing loans, and social guarantor debts (due to errant debtors).

Previous research on the underlying factors affecting financial well-being proved that financial behaviour is one of the main determinants of financial well-being (Abdullah, Fazli, \& Arif, 2019; Mokhtar \& Husniyah, 2017; Sabri \& Zakaria, 2015). However, prior studies revealed mixed findings regarding the antecedents affecting a behaviour that leads to increased financial well-being(Brüggen et al., 2017; Sorgente \& Lanz, 2017). Past research indicated that beyond the importance of knowledge, attitudes and socialisation factors in determining economic behaviour and well-being, psychological factors also have a significant impact on the financial well-being of an individual. Further research was needed to identify the specific psychological factors affecting financial well-being (Brüggen et al., 2017). Thus, by applying the scoping review process, this study will analyse empirical and scholarly research findings on the different types of variable psychological that affecting financial well-being in Malaysia. The researchers also analysed the different types of respondents that have been studied by previous researchers.

As part of literature mapping, we grouped our research questions into two sections: (1) the types of respondents used by the previous studies; and (2) the psychological variables used by the previous studies. Specifically, the first section included the following questions: How many respondents were used by the previous researchers in their study? What types of the respondent group (e.g., student, workers, single mother) were used? The second section was to collect information regarding the different types of psychological variables that affect financial well-being. The following question is: What are the psychological variables concerning financial well-being? Results arising from these two sections will be used to identify the gap for future research about the psychological variables and type of respondent.

\subsection{Literature Review}

Currently, there are various definitions of financial well-being that are informed by previous research. The earliest definition was theorized by Williams (1993)as the objective and subjective measurement of an individual's financial position. (Joo \& Garman, 1998)in a later study stated that financial well-being is the basic concept of financial health that can be measured through the level of material and nonmaterial aspects of financial security, the perception of financial stability, and the actual amount of financial resources.

Malaysian researcher (Zaimah, 2019) concurred with the previous definitions that included both the subjective and objective elements of a person's financial situation. Besides, the Consumer Financial Protection Bureau (CFPB) (2015) in a qualitative study concluded that financial well-being could be achieved when individuals can meet their current and future financial responsibilities, have no worries about their financial future and can make a clear financial decision for the enjoyment of life. Previous researchers often used different terminologies in evaluating an individual's financial well-being such as "satisfaction with savings level", "debt level preparedness", "satisfaction with financial emergency preparedness", "current financial situation", "ability to meet long-term goals", "readiness to meet emergencies", and "skills in financial management". Also, the level of financial distress perceived financial well-being, and financial security have been regularly used (Fazli Sabri, Cook, \& Gudmunson, 2012; Mahdzan, Zainudin, Sukor, Zainir, \& Wan Ahmad, 2019; So-hyun Joo \& John E. Grable, 2004; Yuliandi, Sabri, Rahim, \& Osman, 2018).

\subsection{Methodology}

The scoping review process for this study was documented using Preferred Reporting Items for Systematic studies and Meta-Analyses (PRISMA). PRISMA is regularly used in the natural administration field. It offers three excellent benefits for research which are (1) it clearly describes research results to allow for careful research, (2) it recognizes consolidation and restriction criteria, and (3) it attempts to review an enormous database of coherent writing in a specified time (Sierra-Correa \& Cantera Kintz, 2015).

\subsection{Inclusion criteria}

To identify the available articles to be analysed in our scoping review, three criteria were used:

1) The study was conducted in Malaysia and used Malaysian citizen as respondents.

2) The study had financial well-being as the dependent variable and psychological factors as the independent or moderate or mediated variable (the psychological factor either used as a single variable or combined with another variable).

3) The study has a full-text record written in English.

The initial two criteria were required for recognising records relating to the subject of the scoping review. The English language limitation was applied because English is the global language, and most research is published in English.

\subsection{Search process}

The article search relied on two interdisciplinary electronic journal databases - Scopus and Web of Science (WoS). WoS is a large database comprising of more than 33,000 journals with the inclusion of more than 256 disciplines including subjects related to environmental studies, interdisciplinary social sciences, behavioural studies, economics, and psychology. It includes over 100 years of 
complete back record and reference information set up by Clarivate Analytics and ranks them by three separate measures: citations, papers, and citations per paper (Shaffril, Krauss, \& Samsuddin, 2018).

Scopus is another extensive database. Scopus has indexed over 14,000 social science titles from 4000 publishers, stating that it is the "largest single abstract and indexing database ever built" (Burnham, 2006). Scopus also an exceptionally far-reaching database covering different disciplines, including science, economics, finance, behaviour, and psychology.

\subsection{Systematic review process}

According to PRISMA, there are four steps involved in the scoping review process. The reviewing started in January 2020 with the first step to determine the keywords used for the search process. Depending on the previous studies, keywords related to financial wellbeing and Malaysia were used (Table 1). At this stage, after careful screening, ten duplicated articles were removed.

Table 1. The search string used for the systematic review process

\begin{tabular}{ll}
\hline Database & Keywords used \\
\hline Web of Science & $\begin{array}{l}\text { TS = ("financial welk" OR "economic well" OR "financial satisfaction" } \\
\text { OR "income satisfaction" OR "financial health" OR financial security OR Financial Decision) AND (Malaysia) }\end{array}$ \\
& $\begin{array}{l}\text { TITLE-ABS-KEY ("financial well*" OR "economic well" OR "financial satisfaction" OR "income satisfaction" OR "financial health" OR } \\
\text { financial security OR Financial Decision) AND (Malaysia)) }\end{array}$
\end{tabular}

The following stage was screening. At this stage, out of 62 articles qualified to be investigated, 28 were removed. The third stage is eligibility, where the full articles were accessed. After careful reading, 21 articles were rejected as some did not concentrate on psychological factors as a variable or full text was not found. The last phase of review left a total of 13 articles that were utilized for further investigation.

\subsection{Data abstract and analysis}

The remaining articles were analysed and appropriately assessed — endeavours on specific studies that responded to the formulated research questions. Qualitative analysis was conducted using content analysis to identify different types of psychological variables affecting financial well-being and segregation types of respondent use by previous researchers.

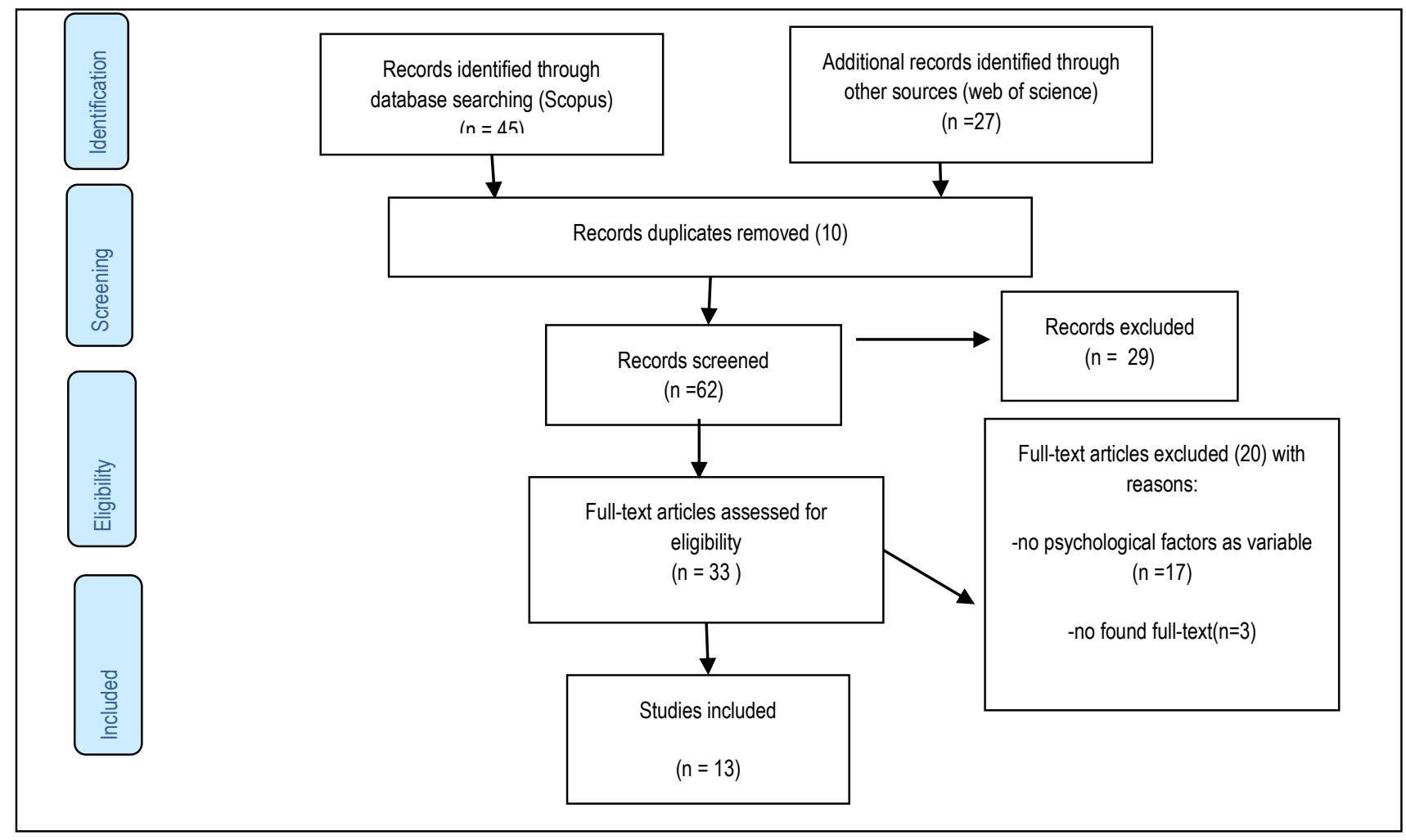

Figure 1: PRISMA diagram selection process

(Sources adapted from D. Moher, A. Liberati, J. Tetzlaff, and D.G. Altman (2009)) 


\subsection{Finding and Analysis}

Table 2: Publication related to types of respondent and psychological variable

\begin{tabular}{|c|c|c|c|}
\hline Authors (year) & Target respondents & Psychological Variable Used & Relationship with financial well-being \\
\hline $\begin{array}{l}\text { Sabri, Wijekoon, and } \\
\text { Rahim (2020) }\end{array}$ & $\begin{array}{l}590 \text { Malaysian Public } \\
\text { Employees }\end{array}$ & $\begin{array}{l}\text { Self-efficacy, } \\
\text { Emotion coping }\end{array}$ & $\begin{array}{l}\text { - A positive association between the general self-efficacy and } \\
\text { FWB). } \\
\text { - People with lower dimensions of self-efficacy demonstrated } \\
\text { a higher degree of decrease in mental well-being. } \\
\text { - Emotion coping has a negative association with the FWB of } \\
\text { Malaysian employees. }\end{array}$ \\
\hline Mahdzan et al. (2019) & $\begin{array}{l}1867 \text { Malaysian low, } \\
\text { middle and high- } \\
\text { income households } \\
\text { Age between } 25-55\end{array}$ & $\begin{array}{l}\text { Financial stress, locus of } \\
\text { control }\end{array}$ & $\begin{array}{l}\text { - Financial stress directly influences subjective financial well- } \\
\text { being in all models tested. } \\
\text { - The result confirmed that the lower stress of an individual } \\
\text { would contribute to a higher score of financial well-being. } \\
\text {-The same result applied for a locus of control where the higher } \\
\text { level of locus of control will contribute to higher levels of } \\
\text { financial well-being }\end{array}$ \\
\hline
\end{tabular}

Zaimah (2019)

Abdullah et al. (2019)

Mokhtar and Husniyah

(2017)

Yuliandi et al. (2018)

Narges and Laily (2011)

Husniyah and Fazilah (2011)
415 married workers in Financial decision making the public sector,

508 respondents aged 40 and below were selected.

203 public employees in Putrajaya, Malaysia age $32-40$

600 single mothers in Malaysia.
Attitudes towards money

Financial stress

Locus of control

Self-coping mechanisms, Financial strains

- Financial decision making by the husband was significant, and it influenced the level of their financial well-being - A more effective and efficient approach in building a family culture that promotes valuable financial decision making should be a concern among the female workers.

- There was a positive relationship between attitudes towards money (inadequacy, effort/ability and retention) and financial well-being.

- A significant correlation between financial stress and financial well-being $\left(r=-628^{* *}, p=.000\right)$, indicating that the lower the financial stress of an individual, the higher the level of financial well-being.

- Locus of control are proving to be correlated with financial well-being as well $\left(r=.264^{* \star}, p=.000\right)$.

- There were significant positive relationships found between self-copying mechanisms, financial strains, and financial security.

- There is an indirect mediation effect of self-copying mechanisms on the relationship between financial strains and financial security.

- Financial stress has a direct negative relationship with financial wellness. public and private sectors 800 urban and rural family financial managers in Peninsular Malaysia

Financial Stress

Financial risk tolerance, future time orientation, self-worth

- The significant predictors for the financial stability of urban families were financial risk tolerance, future time orientation, and self-worth of family financial managers while for rural families; only one significant predictor was found that was selfworth.

The practice of moderation (the concept of wasatiyyah)(Islamic collected from the selected group of Muslim consumers aged around 20-40

- Moderation (wasatiyyah) partially mediates the relationship between materialism and financial decisions.

- Consequently, Muslim consumers who practice moderation while making their financial decisions are more conscious of their credit management and thus spend according to their means

Relationship with financial well-being

\begin{tabular}{llll}
\hline Authors (year) & Target respondents & Psychological Variable Used & Relationship with financial well-being \\
\hline Sabri and Zakaria (2015) & $\begin{array}{l}508 \text { of young } \\
\text { employees aged 40 } \\
\text { and under in central } \\
\text { zone of Malaysia }\end{array}$ & $\begin{array}{l}\text { Money attitude } \\
\text { Self-esteem }\end{array}$ & $\begin{array}{l}\text { - Domains in money attitude had a significant influence on } \\
\text { financial well-being }\end{array}$ \\
& & $\begin{array}{l}\text { - Self-esteem did not make any contribution to the financial } \\
\text { well-being of young employees. }\end{array}$
\end{tabular}

Sabri, Paim, Falahati, and 2246 employees in Masud (2013) public and private sectors, in which 1122 were from public sectors and 1124 were from private sectors
Financial stress

- Financial stress was the most significant variable in predicting financial well-being among public and private sector employees. 
2,219 college students across Malaysia
Childhood consumer experience
- Childhood consumer experiences such as savings habits contribute to students' financial well-being (money saved current financial situation, and financial management skills).

\subsection{Types of respondent and psychological variables}

The review conducted by researchers shows that parallel with the international studies, the financial well-being studies in Malaysia used the different types of the respondent according to the researcher's motivation and individual as a unit of analysis. The majority of the research used workers either from the public or private sector as their respondents (Abdullah et al., 2019; Mokhtar \& Husniyah, 2017; Sabri et al., 2013; Sabri et al., 2020; Sabri \& Zakaria, 2015; Zaimah, 2019). However, there was no differentiation with regards to their work categories. It was noted that there are studies that focus on both public and private sector respondents where the results can allow to the researchers to make a comparative analysis between these sectors (Narges \& Laily, 2011; Sabri et al., 2013; Zaiton, Erni Marlina, \& Phang, 2018).

In addition, there are some exciting studies that focus on a particular group of respondents such as college students (Fazli Sabri et al., 2012), young employees (Abdullah et al., 2019; Mokhtar \& Husniyah, 2017; Sabri \& Zakaria, 2015), single mothers (Yuliandi et al., 2018), and Muslim individuals (Ramlee et al., 2019). Targeting respondents of a specific group will enable researchers to learn about the group's particular issues. These studies have the advantage of enabling researchers to arrive at an appropriate solution or action tailored to the respondent group. For example, the study by Ramlee et al. (2019) about Malaysian Muslims found that the Muslims who practice moderation (Wasatiyyah) in their life will increase their financial well-being. The latest research was done by (Mahdzan et al., 2019) also shows a significant impact on financial well-being. Separating the respondents into three income level groups (lower, middle and higher income) has shown that people of different income levels should be treated differently to increase their financial well-being.

Furthermore, psychology is one of the personal factors that should be a concern to researchers in the field of financial wellbeing(Brüggen et al., 2017). Of significance to mainstream research, the study of financial well-being in Malaysia always puts the psychological variable as one of many that may influence financial well-being. There are 11 types of psychological variables found in financial well-being studies, including financial stress (Mahdzan et al., 2019; Mokhtar \& Husniyah, 2017; Narges \& Laily, 2011; Sabri et al., 2013; Yuliandi et al., 2018; Zaiton et al., 2018), self-efficacy (Sabri et al., 2020), self-copying (Sabri et al., 2020; Yuliandi et al., 2018), locus of control (Mahdzan et al., 2019; Mokhtar \& Husniyah, 2017), financial decision making (Mahdzan et al., 2019), attitude towards money (Abdullah et al., 2019; Sabri \& Zakaria, 2015), financial risk tolerance (Husniyah \& Fazilah, 2011), self-esteem (Sabri \& Zakaria, 2015), self-worth (Husniyah \& Fazilah, 2011), childhood consumer experience (Fazli Sabri et al., 2012), and Islamic moderation practice (wasatiyyah) (Ramlee et al., 2019)

Among these variables, financial stress is the most frequently used and has a significant negative result on financial well-being. All other psychological variables had the same significant result except self-esteem(Sabri \& Zakaria, 2015), which was found not to have any effect on young employees' financial well-being. However, the majority of psychological variables are derived from the western perspective, and only one researcher was found who uses the Islamic psychological variable in their study. The study by (Ramlee et al., 2019) introduced the concept of Islamic moderating practice (wasatiyyah) as a potential psychological variable that may improve Muslims' financial decisions. The result demonstrates that the Islamic concept of moderation (wasatiyyah) helps Muslims make the right decisions in their finances.

\subsection{Conclusion and direction for future research}

Despite the different respondent groups used by the researchers in the financial well-being studies, there is still a gap where there are particular group needs attention due to the alarming financial well-being situation. For example, a report by AFBES'18 (2018) highlights that those working in enforcement (army and police) score the lowest on financial well-being. AFBES'18 (2018) stress that this group are unable to cover three months' expenses if they face retrenchment. This phenomenon is a wake-up call to researchers and the government. To date, many researchers in Malaysia focus on private and public sector employees, but there has been no financial wellbeing study done specifically on the enforcement group. A study on the enforcement group (Armed forces as an example) is relevant because they are the backbone of Malaysia's defence, and it is essential to monitor and cater to their well-being, especially financial well-being. To add, a study by Hester (2017) in the US shows how the US army has a radical way in dealing their financial stress including increased risk of suicide and decreased physical and mental health, which damages the family's functioning. Given the alarming trend, more analyses regarding the financial well-being of the enforcement groups are crucial and in need of attention from government and scholars.

Although the world is beginning to pay special attention to the financial well-being of emerging adults (20 to 30 -year-olds) (Brüggen et al., 2017; Sorgente \& Lanz, 2017, 2019), there is no attention given by Malaysian researchers toward this group. According to (Sorgente \& Lanz, 2017), the current researchers and governments focus should be on the emerging adult's group because they are the most affected by the economic crisis of 2008. Additionally, emerging adults, as neither adolescents nor adults, can be either students or workers or both. This situation and condition must be carefully studied to detect the development of emerging adults from half financial autonomy (students supported by their parent) to full their financial autonomy (with a working career). Towards achieving the SDGs, the focus should be on this age group because by 2030, they will become adults, and pre-emptive measures taken by the government through the suggestion of researchers will help the emerging adults to improve their financial well-being hence uplifting their quality of life. 
Until now, the majority of previous studies have focused on psychological variable adapted from a western perspective, and there is still a lack of research that looking psychological factors form others views such as Islamic psychological that possible to effect on financial well-being. Taken into account that Malaysia's population is $61 \%$ Muslim, it's a good start for Malaysian researchers to explore any Islamic psychological variable that may influence financial well-being. The introduction of the Wasatiyyah(The concept of moderation from the Islamic perspective) in the study by Ramlee et al. (2019) proves that Islamic psychological variable can be explored as a new variable that can be new contributing factors in increasing financial well-being. This gap is an opportunity for Muslim scholars to explore new dimensions of Islamic psychological concepts, such as Reda (Islamic acceptance), Syukur (Islamic thankfulness), and Qanaah (Islamic self-contentment) which can show researchers support in finding new factors in improving the public financial well-being as stated in Malaysian National Strategy for Financial Literacy.

\section{Acknowledgements}

This paper draws from grants awarded by the Ministry of Higher Education (MOHE), Malaysia under the Fundamental Research Grant Scheme for Research Acculturation of Early Career Researchers (FRGS-RACER) Phase 1/2019

Grant No: RACER/1/2019/SS01/UITM//6.

\section{References}

Abdullah, N., Fazli, S. M., \& Arif, A. M. M. (2019). The Relationship between attitude towards money, financial literacy and debt management with young worker's financial well-being. Pertanika Journal of Social Sciences and Humanities, 27(1), 361-387. Retrieved from https://www.scopus.com/inward/record.uri?eid=2-s2.085064613743\&partnerlD=40\&md5=e141009ec3c36fd1acdd8603a2638c3c

AFBES'18. (2018). AKPK Financial Behaviour and State of Finanical Well-being of Malaysian Working Adult. AKPK Financial Behaviour Survey 2018 (AFBES'18).

Andrea Finney. (2016). Defining, measuring and predicting financial capability in the UK: A Technical Report. Money Advice Service's Financial Capability. doi:10.13140/RG.2.2.14086.27206

Brüggen, E. C., Hogreve, J., Holmlund, M., Kabadayi, S., \& Löfgren, M. (2017). Financial well-being: A conceptualization and research agenda. Journal of Business Research, 79, 228-237. doi:10.1016/j.jbusres.2017.03.013

Burnham, J. F. (2006). Scopus database: a review. Biomed Digit Libr, 3, 1. doi:10.1186/1742-5581-3-1

Consumer Financial Protection Bureau (CFPB). (2015). Consumer Response Annual Report 2015. Consumer Financial Protection Bureau.

D. Moher, A. Liberati, J. Tetzlaff, \& D.G. Altman. (2009). Preferred reporting items for systematic reviews and meta-analyses: the PRISMA statement. PLoS Med.,, 6(7). doi:10.1371/journal.pmed1000097

Fazli Sabri, M., Cook, C. C., \& Gudmunson, C. G. (2012). Financial well-being of Malaysian college students. Asian Education and Development Studies, 1(2), $153-170$. doi:10.1108/20463161211240124

Financial Education Network. (2019). Malaysia National Strategy for Financial Literacy 2019-2023. Bank Negara Malaysia.

Gutter, M., \& Copur, Z. (2011). Financial behaviors and financial well-being of college students: Evidence from a national survey. Journal of Family and Economic Issues, 32(4), 699-714. doi:10.1007/s10834-011-9255-2

Hester, R. D. (2017). Lack of access to mental health services contributing to the high suicide rates among veterans. Int J Ment Health Syst, 11, 47. doi:10.1186/s13033017-0154-2

Husniyah, A. R., \& Fazilah, A. S. (2011). Factors contributing to financial stability of urban and rural families. Pertanika Journal of Social Science and Humanities :

Joo, S., \& Garman, E. T. (1998). The relationship between personal financial wellness and employee productivity: A conceptual model. Personal Finances and Worker Productivity, 2(2), 162-171.

Mahdzan, N. S., Zainudin, R., Sukor, M. E. A., Zainir, F., \& Wan Ahmad, W. M. (2019). Determinants of Subjective Financial Well-Being Across Three Different Household Income Groups in Malaysia. Social Indicators Research, 146(3), 699-726. doi:10.1007/s11205-019-02138-4

Mokhtar, N., \& Husniyah, A. R. (2017). Determinants of Financial Well-Being among Public Employees in Putrajaya, Malaysia. Pertanika Journal of Social Science and Humanities, 25(3), 1241-1260. Retrieved from $\leq$ Go to IS|>://WOS:000426845200014

Murugiah, L. (2016). The Level of Understanding and Strategies to Enhance Financial Literacy among Malaysian. International Journal of Economics and Financial Issues, 6(S3), 130-139.

Narges, D., \& Laily, H. P. (2011). Determinants of financial wellness among Malaysia workers. African Journal of Business Management, 5(24), $10092-10100$. doi:10.5897/ajbm10.1267

O'Neill., B., Sorhaindo., B., Xiao., J. J., \& Garman., E. T. (2005). Financially Distressed Consumers: Their Financial Practices, Financial Well-being, and Health. Association for Financial Counseling and Planning Education, 73-87.

Pradhan, P., Costa, L., Rybski, D., Lucht, W., \& Kropp, J. P. (2017). A Systematic Study of Sustainable Development Goal (SDG) Interactions. Earth's Future, 5(11), 1169-1179. doi:10.1002/2017EF000632 
Prawitz, A. D., Garman, E. T., Sorhaindo, B., O'Neill, B., Kim, J., \& Drentea, P. (2006). doi:10.1037/t60365-000

Ramlee, R., Syed Mohd Zain, S. R., \& Wan Husain, W. R. (2019). Are muslims practising moderation in their financial decisions? Asian Academy of Management Journal, 24, 157-170. doi:10.21315/AAMJ2019.24.S1.11

Sabri, M. F., Paim, L., Falahati, L., \& Masud, J. (2013). Determinants of employees' financial well-being: The moderation effect of work sectors. MALAYSIAN JOURNAL OF CONSUMER AND FAMILY ECONOMICS, 16(1), 91-105. Retrieved from https://www.scopus.com/inward/record.uri?eid=2-s2.084940225099\&partnerID=40\&md5=3dd4b97948d25d73a8e6128707a1d729

Sabri, M. F., Wijekoon, R., \& Rahim, H. A. (2020). The influence of money attitude, financial practices, self-efficacy and emotion coping on employees' financial wellbeing. Management Science Letters, 10(4), 889-900. doi:10.5267/j.msl.2019.10.007

Sabri, M. F., \& Zakaria, N. F. (2015). Financial well-being among young employees in Malaysia. In Handbook of Research on Behavioral Finance and Investment Strategies: Decision Making in the Financial Industry (pp. 221-235).

Shaffril, H. A. M., Krauss, S. E., \& Samsuddin, S. F. (2018). A systematic review on Asian's farmers' adaptation practices towards climate change. Science of The Total Environment, 644, 683-695. doi:https://doi.org/10.1016/j.scitotenv.2018.06.349

Sierra-Correa, P. C., \& Cantera Kintz, J. R. (2015). Ecosystem-based adaptation for improving coastal planning for sea-level rise: A systematic review for mangrove coasts. Marine Policy, 51, 385-393. doi:10.1016/j.marpol.2014.09.013

So-hyun Joo, \& John E. Grable. (2004). An exploratory framework of the determinants of financial satisfaction. Journal of Family and Economic Issues, 25(1), $25-50$.

Sorgente, A., \& Lanz, M. (2017). Emerging Adults' Financial Well-being: A Scoping Review. Adolescent Research Review, 2(4), 255-292. doi:10.1007/s40894-016-0052-

Sorgente, A., \& Lanz, M. (2019). The multidimensional subjective financial well-being scale for emerging adults: Development and validation studies. International Journal of Behavioral Development, 43(5), 466-478. doi:10.1177/0165025419851859

United Nations. (2015). Agenda for Sustainable Development. sustainabledevelopment.un.org.

Williams, F. L. (1993). Financial counseling: Low-income or limited-income families. In V. S. Fitzsimmons (Ed.), Economic changes: Challenges for financial counseling and planning professionals. Proceedings of the Association for Financial Counseling and Planning Education, 121-145.

Xiao, J. J. (2013). Family Economic Well-Being. In G. W. Peterson \& K. R. Bush (Eds.), Handbook of Marriage and the Family (pp. 573-611). Boston, MA: Springer US.

Yuliandi, S., Sabri, M. F., Rahim, H., \& Osman, S. (2018). The mediation effect of self-coping mechanism between financial strains and financial security of single mothers in Malaysia. Malaysian Consumer and Family Economics Association, 21, 102-123.

Zaimah, R. (2019). The probability factor influences the level of financial well-being of workers in Malaysia. Geografia-Malaysian Journal of Society \& Space, 15(3), 122135. doi:10.17576/geo-2019-1503-09

Zaiton, O., Erni Marlina, M., \& Phang, I. (2018). In Pursuit of Financial Well-being: The Effects of Financial Literacy, Financial Behaviour and Financial Stress on Employees in Labuan. nternational Journal of Service Management and Sustainability, 3, 55-94. 